\title{
Development of Performance Evaluation Model for Public Sector Industrial Organizations in Kerala
}

\author{
Sibu C. Chithran, K.S.Chandrasekar,
}

\begin{abstract}
The performance of public sector industrial organizations always occupies in the front page of newspapers and headlines among mass media. The public sector industrial organizations in Kerala, in fact, suffer from various problems all the time. The aim of the study was to examine the systems of performance evaluation existing in the various public sector industrial organizations under manufacturing sector in Kerala and to identify the relevant criteria for establishing an objective performance evaluation system and to develop a model for proper evaluation. An attempt was also made to highlight the real problems with a view to suggest remedial measures. To achieve the objectives an extensive in-depth literature review as well as an elaborate field survey were carried out. For the investigation in the field, 18 industrial organizations from among 42 existing public sector industrial organizations in Kerala under manufacturing sector were selected and with the help of a set of structured questionnaires/interview schedules, the required data for the purpose were collected through personal interviews and discussions with the concerned managing directors/chief executives and department heads of the organizations. The data collected were analyzed scientifically using appropriate statistical tolls and interpreted. The findings thus obtained were made along with the respective recommendations.
\end{abstract}

Keywords: Performance Evaluation, Public Sector Industrial Organizations, Manufacturing Sector, Corporate Management, Model Development

\section{INTRODUCTION}

An advancing and expanding public sector is an indispensible pre-requisite to speedy economic development, particularly in a developing country like India. Over the years, the Indian public sector has witnessed an enormous growth which is evident from the total investment in public sector in the plan outlays. The success of the Indian economy in terms of growth and distributive justice largely hinges on the performance of public sector organizations. Both central and state governments depend on the good performance of this sector a lot to achieve their socio-economic objectives.

During the early stages of industrialization, the performance of public sector industrial organizations comes in for severe criticism from inside and outside the country. The controversial issues were their role in the economic

Revised Manuscript Received on September 22, 2019.

Dr. Sibu C. Chithran, Professor and Head, Department of Management studies, Mangalam College of Engineering, Ettumanur, Kottayam sibuktm@gmail.com

Dr.K.S.Chandrasekar, Professor and Dean, IMK, University of Kerala, Trivandrum kscnair@gmail.com development forms of organizations, financing, governing boards, ministerial control, public accountability, efficiency, management, goals and measurements, human resource management, financial management, materials management, industrial relations, employees' motivation, etc. The choice of investment, inadequate project preparation, in experienced management, non-differential relationship between the government and the organizations and such other factors were the main reasons for the poor performance of public sector organizations. Also they have been suffering from other problems such as, economic inefficiency as indicated by low profitability, high cost of production and low capacity utilization and over capitalization, outdated technology, increased competition from private sector, too much accountability at one hand and lack of autonomy on the other, over dependence on government on finances etc., which ultimately constitute to the budgetary deficit of the country. Even though these weaknesses have not been completely corrected, their performance has generally improved for the last few years.

This study purports to a performance evaluation of modern manufacturing category of public sector industrial organizations in the state of Kerala. Over the years, there has been an impressive growth in the number of public sector industrial organizations in Kerala. It may be noted that Kerala has the largest number of state level public sector industrial organizations in India. Out of 113 public sector industrial organizations, 42 units were under modern manufacturing category. The total capital invested towards the public sector industrial organizations during the period of study was Rs. 1,17,276.81 lakhs, but the return on this investment was abysmally poor as a result of which the net worth had become a shocking amount of Rs. 4,95,954.78 lakhs. The accumulated loss of the state public sector stood at a staggering figure of Rs. 15,266.39 lakhs. All these point to the series lapses in the system. As a result, public sector industrial organizations in Kerala and their proper evaluation have become important areas of discussion. An opinion has been created that one of the reason for the economic backwardness of the country was the insufficient performance of public sector organizations. On the basis of this, there has been a wide spread demand to restructure these organizations in such a way as to make them profitable and self sustaining. 


\section{OBJECTIVITIES OF THE STUDY}

The research has been carried out by keeping the following objective in mind.

1. To examine the systems of performance evaluation existing in public sector industrial organizations in Kerala.

2. To identify the relevant criteria for establishing an objective performance evaluation system.

3. To develop a model for evaluating the overall performance of the public sector industrial organizations in Kerala based on their different categories.

4. To highlight the real problems existing in this regard and to suggest remedial measures.

\section{LITERATURE REVIEW}

Fitz Patrick (1930) analyzed ratios for failed and non-failed forms, at three years period of failure, by selecting 19 companies randomly which had failed during 1920-29. He concluded that the ratios of failed firms were persistently different from non-failed firms, at least three years prior to failure. So the ratios were important tools in ascertaining relationships of business facts and observed that, the net worth to debt and net profits to net worth were the best indicators to failure among the ratios used.

Arthur Winker and Raymond F. Smith (1935) examined 183 firms which failed between 1923-31 for ten years prior to the year of failure. The study concluded that the ratios of the failed firms were frequently below the mean value used for comparison and showed deterioration as the date of failure drew near and also pointed out that the ratios of net working capital to total assets was the most accurate and steady indication of failure as well as an earlier indication of unfavourable trends in financial health.

R. Ramsess and L.O. Foster (1940) analyzed 11 types of financial ratios for 173 firms whose securities were registered in the State if Illinois. It was found that, forms which turned out to be less successful, and those, which failed, tended to have ratios of which were lower than the more successful firms. However, two turnover ratios, sales to net worth and sales to total assets, exhibited an opposite tendency.

Charles L. Merwin (1942) by using a sample of over 900 firms of continuing and discontinuing firms corroborated the ratio differences far back as six years before failure. He concluded that, the deviations of certain credit ratios from an empirically determined level as definite diagnostic value.

Moore and Atkinson (1952) found that borrowing firms with poorer current ratios and net worth to debt ratios were more prone to loan default and ability to obtain credit was correlated with several ratios.

Saiden (1956) reported that certain financial ratios were inversely correlated with loaded credit difficulties, for example, net working capital to total assets.

W.B. Hickman (1958) found that the times interest earned ratio and the net profit's sales ratio were useful creditors of the default experiences of corporate bond issues during 1900-1943.

M. Tamaris (1960) was carried out the first multivariate study in which weighted composite of several ratios were used to indicate the possibility of failure. He introduced new financial ratios in the model, generally accepted in practice as indicators of financial soundness. These selected ratios were given certain weights according to their importance in the eyes of financial analysts, economists and credit-men.

W.H. Beaver (1966) attempted to demonstrate that the failure of enterprises could be predicted reliably through the combined utilization of sophisticated quantitative techniques and financial ratios.

Edward Altman (1968) adopted the multiple discriminant analysis as an appropriate statistical technique. He had developed the model by collecting necessary data relating to the objects in the groups and there by deriving their linear combination, which becomes a discriminant function between the groups. Based on the financial ratios of certain selected companies, he has evolved a set of discriminant coefficients, which when applied to actual ratios formed mutually exclusive groupings.

David Ewert (1968) investigated on the basis of information supplied in the Dun and Bradstreet credit reports that ratios can predict non-repayment of receivables, keeping $82 \%$ accuracy.

Marc P. Blum (1969) constructed a theoretical model based on accounting and financial market data, which was designed to discriminate between failing and non-failing firms. He defined failure as entrance to bankruptcy proceeding or an explicit agreement with creditors which reduced the debts of the company.

Pail A. Meyer and Howard W. Pifer (1970) attempted to build up a model for the prediction of bank failure. They identified certain factors which affects bank failure and divided them into four groups viz., local economic conditions, general economic conditions, quality of management and integrity of employees.

Craig Johnson (1971) argued that ratio-discriminant model is not dynamic in nature and therefore cannot capture whatever time series contribution was relevant towards failure contributions.

Robert Edminister (1971) found that using a ratio function could make good predictions. He attempted to improve the quality of ration analysis by considering average ratios, ratio trend, ratio level and the interaction of trend and level. He concluded that the linear combination of theser variables could produce better prediction.

M.S. Gills and G.P. Jenkins (1977) of the Boston Area Group in Public Enterprise (BAGPE) research have clearly rejected the use of traditional analysis for state-owned organizations.

The Composite Productivity Index (1981), which was developed as an outcome of an International Seminar organized by United Nations and Government of Pakistan, resources to selecting certain indicators that generally reflect the performance of any organization that has motive of doing business. As far as possible it was taken into consideration that the indicators or criteria for performance evaluation were representative in nature.

Trivedi Prajapathi (1990) explores the applicability of introducing the French System of Contracts in less developed countries for better performance. The main thrust of these contracts in France 
was to reorient the management of public sector undertakings from a system of priori control to a system of posteriori control. They are thereby classified into various categories such as the Signaling System practiced in Korea, Pakistan and Venezuela, and the Performance Contract Approach of Bangladesh. In this context, Trivedi also analyzes the Indian version of Contract System viz., the Memorandum of Understanding.

Trivedi Prajapathi and H.P. Vithal (1992) were more on the side of private profit. They were of the opinion that profit was comparable to food and hence public profit should be shunned as a criterion of state-owned organizations.

Prasanna Chandra (1998) comments on a model for assessing corporate excellence developed by The Economic Times- Howard Business School Association of India (ET-HBSAI) which considers five financial indicators - viz., gross surplus ratio, sustainable growth rate, net profit return on net worth, creation of value and cash flow - in its quantitative evaluation.

M. Zeppou and T. Sotirakou (2004) has stated that STAIR model has been used in Greek public sector, as the appropriate performance management and measurement framework for identifying the factors that prevent organizations to fully benefit from the regular use of performance management process. STAIR stands for strategy, targets, assignment, implementation and results. developed taking into account the conditions obtaining in the private sector companies in the developed countries. It may not be therefore possible to apply any of these methods in case of public sector undertakings either at central or state level. However, some of the approaches of ratio analysis, whether a system can be developed for the performance evaluation of public sector undertaking in Kerala is a possible area of further study.

\section{METHODOLOGY}

The design of research covered both experimental and descriptive styles. Methodology consisted mainly of field work. Primary and secondary data were also collected as and when required. The secondary data have been collected from published books, periodicals, pamphlets, annual reports, Articles of Association of the industrial organizations, Economic Review, Review of Public Enterprises in Kerala, etc. Unpublished documents, government orders and information collected through empirical survey and interview with the Managing Directors or Chief Executives and the various department heads of industrial organizations under manufacturing sector comprised the major chunk of primary data. Those executives and department heads were interviewed with the help of a set of carefully prepared interview schedules/questionnaires comprised of both qualitative and quantitative types of questions. It covered the areas of Corporate Management, Human Resource Management, Financial Management, Production Management, Research and Development and Marketing Management. The interview schedule/questionnaire relating to Corporate Management was general in nature and as such it was used to collecting the data from Managing Directors or Chief Executives. Other interview schedules/questionnaires
Most of the above methods of performance evaluation were

were functional basis and hence were used to obtain information from the corresponding department heads. An opinion survey of the management personnel of the industrial organizations was also conducted as a part of the study. Due to constraints of time and sources, the study was made a sample study instead of census study.

The study focus on the performance of public sector organizations under modern manufacturing category, which comes to 42 units in the state of Kerala. The main reasons to select the manufacturing category of industrial organizations alone for the purpose of study are:

Although, studies on the other categories, such as development and infrastructural agencies, traditional industries, trading units, public utilities, welfare and other agencies, have been made at the intense of various funding and other national and international agencies, not much has been done on the modern manufacturing category.

It is presumed that, the public sector industries under the manufacturing category have to sustain and grow in a more competitive environment than the others and it would be possible only if they can perform satisfactorily.

Further, unlike other categories, the amount of social obligations is much limited in the manufacturing sector.

Depending on the type of the industry, the manufacturing category was further divided into eight industry groups as shown in Table 1. Out of the 42 public sector organizations under manufacturing sector, 14 units had made profits and 28 units incurred losses during the period of study as depicted in Table 2.

It was then attempted to group the units in terms of their size into small, medium and large categories. The units which employ upto 150 were classified as small, those which employ from 151 to 500 were classified as medium and the rest employ more than 500 were classified as large as per the classification of Bureau of Public Enterprises, Government of Kerala as reproduced in Table 3 .

Table 1 Industry Group-wise Public Sector Organizations under Manufacturing Sector in Kerala

\begin{tabular}{|c|l|c|}
\hline $\begin{array}{c}\text { Sl. } \\
\text { No: }\end{array}$ & \multicolumn{1}{|c|}{ Industry Group } & $\begin{array}{c}\text { No: of } \\
\text { Units }\end{array}$ \\
\hline 1 & Ceramic and Refractories & 2 \\
\hline 2 & Chemical Industries & 7 \\
\hline 3 & Electrical Equipment & 4 \\
\hline 4 & Electronic Industries & 6 \\
\hline 5 & Engineering Industries & 9 \\
\hline 6 & $\begin{array}{l}\text { Plantation and Agro-based } \\
\text { Industries }\end{array}$ & 9 \\
\hline 7 & Textile Industries & 3 \\
\hline 8 & Wood-based Industries & 2 \\
\hline & \multicolumn{2}{|c|}{ Total } \\
\hline
\end{tabular}

Table 2 -Profit and Loss of Industry Group-wise Public Sector Organizations Under Manufacturing Sector in Kerala 


\begin{tabular}{|c|c|c|c|c|c|c|c|c|c|}
\hline $\begin{array}{c}\text { Prof } \\
\text { it or } \\
\text { Loss }\end{array}$ & $\begin{array}{c}\text { Ceramic } \\
\text { and } \\
\text { Refractori } \\
\text { es }\end{array}$ & $\begin{array}{c}\text { Chemic } \\
\text { al } \\
\text { Industri } \\
\text { es }\end{array}$ & $\begin{array}{c}\text { Electrical } \\
\text { Equipme } \\
\text { nt }\end{array}$ & $\begin{array}{c}\text { Electron } \\
\text { ic } \\
\text { Industri } \\
\text { es }\end{array}$ & $\begin{array}{c}\text { Engineeri } \\
\text { ng } \\
\text { Industries }\end{array}$ & $\begin{array}{c}\text { Plantati } \\
\text { on and } \\
\text { Agro- } \\
\text { based } \\
\text { Industri } \\
\text { es }\end{array}$ & $\begin{array}{c}\text { Textile } \\
\text { Industri } \\
\text { es }\end{array}$ & $\begin{array}{c}\text { Wood- } \\
\text { based } \\
\text { Industri } \\
\text { es }\end{array}$ & $\begin{array}{c}\text { Tot } \\
\text { al }\end{array}$ \\
\hline $\begin{array}{c}\text { Profi } \\
t\end{array}$ & 1 & 3 & 1 & 1 & 3 & 4 & 0 & 1 & 14 \\
\hline $\begin{array}{c}\text { Loss } \\
\text { Tota }\end{array}$ & 1 & 4 & 3 & 5 & 6 & 5 & 3 & 1 & 28 \\
\hline
\end{tabular}

Table 3

Classification of Public Sector Organizations

Under Manufacturing Sector based on Employees Strength

\begin{tabular}{|c|c|c|c|c|}
\hline \multirow{2}{*}{$\begin{array}{c}\text { Profit or } \\
\text { Loss }\end{array}$} & \multicolumn{3}{|c|}{$\begin{array}{c}\text { Classification based on } \\
\text { Employee Strength }\end{array}$} & \multirow{2}{*}{ Total } \\
\cline { 2 - 4 } & Small & Medium & $\begin{array}{c}\text { Larg } \\
\text { e }\end{array}$ & \\
\hline Profit & 3 & 4 & 7 & 14 \\
\hline Loss & 7 & 13 & 8 & 28 \\
\hline Total & 10 & 17 & 15 & $\mathbf{4 2}$ \\
\hline
\end{tabular}

Using the random table, out of these 42 units, 18 public sector industrial organizations under manufacturing sector were identified by giving each organization an identification number, starting from 001. Finally, after 18 iterations, identified organizations which are in both profit making and loss making.

The data collected were processed and analyzed scientifically using SPSS. The processing implied editing, coding, classification and tabulation. A qualitative analysis of the statements by the respondents was made and generalized conclusions were then drawn. An analysis of the quantitative data was also carried out to get a clear picture of the performance scenario. The data was also analyzed with a view to establish correlative relationships between different parameters. Different tools of research were used for the study were Analysis of Variance, Kruskal-Wallis Test, Correlation, Chi-Square Test, Destination Ranking, Multiple Regression and Percentage Analysis. Criteria for positive performance were fixed. Reasons for poor performance were established. Conclusions were also drawn on the basis of survey responses.

\section{DATA ANALYSIS}

Based on the purpose of the research, data were collected from the 18 public sector industrial organizations under manufacturing sector in Kerala.

\subsection{Corporate Management}

The responses of various Managing directors or Chief Executives from the 18 public sector industrial organizations were gathered and arrived at the following inferences.
Most of the organizations were having the tenure of more than 30 years and took less than a year for roll-out their first product. The role of board of directors was effective and the chief executives were appointed by the state government with an average tenure of 3 to 5 years which found to be insufficient as per their opinion which resulted in the adverse performance of the organizations. Even though, they had good relationships with the board of directors and top management. In most of the cases, those organizations were not able to perform as per the corporate plan due to the absence of proper decision making process.

For analyzing the effectiveness of various systems viz., communication system, reporting system, coordination system and control system, the opinion of chief executives were collected and Kruskal-Wallis test has been carried out to know whether there is any difference in between the industrial groups regarding their effectiveness of those systems. Table 4 reveals the results.

Table 4 -Responses Regarding the Various Systems in the Organizations

\begin{tabular}{|c|c|c|c|c|c|}
\hline \multirow{2}{*}{$\begin{array}{l}\text { Sl. } \\
\text { No: }\end{array}$} & \multirow{2}{*}{ Responses } & \multicolumn{4}{|c|}{ Systems } \\
\hline & & $\begin{array}{c}\text { Communication } \\
(\%)\end{array}$ & $\begin{array}{c}\text { Reporting } \\
(\%)\end{array}$ & $\begin{array}{c}\text { Coordination } \\
(\%)\end{array}$ & $\begin{array}{c}\text { Control } \\
(\%)\end{array}$ \\
\hline 1 & Very Good & $\begin{array}{c}2 \\
(11.11 \%)\end{array}$ & $\begin{array}{c}3 \\
(16.67 \%)\end{array}$ & $\begin{array}{c}3 \\
(16.67 \%)\end{array}$ & $\begin{array}{c}2 \\
(11.11 \%)\end{array}$ \\
\hline 2 & Good & $\begin{array}{c}8 \\
(44.44 \%)\end{array}$ & $\begin{array}{c}10 \\
(55.56 \%)\end{array}$ & $\begin{array}{c}10 \\
(55.56 \%)\end{array}$ & $\begin{array}{c}9 \\
(50.00 \%)\end{array}$ \\
\hline 3 & Satisfactory & $\begin{array}{c}7 \\
(38.89 \%)\end{array}$ & $\begin{array}{c}5 \\
(27.77 \%)\end{array}$ & $\begin{array}{c}4 \\
(22.22 \%)\end{array}$ & $\begin{array}{c}7 \\
(38.89 \%)\end{array}$ \\
\hline 4 & Poor & $\begin{array}{c}1 \\
(5.56 \%)\end{array}$ & $\begin{array}{c}0 \\
(0.00 \%)\end{array}$ & $\begin{array}{c}1 \\
(5.56 \%)\end{array}$ & $\begin{array}{c}0 \\
(0.00 \%)\end{array}$ \\
\hline 5 & Very Poor & $\begin{array}{c}0 \\
(0.00 \%)\end{array}$ & $\begin{array}{c}0 \\
(0.00 \%)\end{array}$ & $\begin{array}{c}0 \\
(0.00 \%)\end{array}$ & $\begin{array}{c}0 \\
(0.00 \%)\end{array}$ \\
\hline & Total & $\begin{array}{c}18 \\
(100.00 \%)\end{array}$ & $\begin{array}{c}18 \\
(100.00 \%)\end{array}$ & $\begin{array}{c}18 \\
(100.00 \%)\end{array}$ & $\begin{array}{c}18 \\
(100.00 \%)\end{array}$ \\
\hline & ean Scores & 3.61 & $3 . .89$ & 3.83 & 3.72 \\
\hline \multirow{2}{*}{\multicolumn{2}{|c|}{$\begin{array}{l}\text { Kruskal-Wallis test } \\
\text { (between Industrial } \\
\text { groups) }\end{array}$}} & $\chi^{2}=3.82$ & $\chi^{2}=7.118$ & $\chi^{2}=7.607$ & $\chi^{2}=4.436$ \\
\hline & & $\mathrm{P}$-value $=0.576$ & $\begin{array}{l}\mathrm{P} \text {-value }= \\
0.212\end{array}$ & $\mathrm{P}$-value $=0.179$ & $\begin{array}{l}P \text {-value }= \\
0.489\end{array}$ \\
\hline
\end{tabular}

Table 4 interpreted that in all systems, mean values were above 3 i.e., satisfactory. Kruskal-Wallis test showed that there was no difference in the effectiveness of various systems in between the various industrial groups at 5\% level of significance.

Destination ranking was applied with a view to rank the various departments as per the opinion of chief executives. To calculate a summary rank order, the departments having the first or highest preference was given the lowest number (1) and the least or lowest preferred functional area was given the highest number (5). The result thus made was given in Table 5 . 
As per Table 5, production department ranked first followed by finance department, marketing department and human resource department. It was research and development department lags behind all other functional areas.

Table 5

Ranking of Various Departments in the Organizations

\begin{tabular}{|c|c|c|c|}
\hline $\begin{array}{c}\text { Sl. } \\
\text { No: }\end{array}$ & Rank & Departments & Score \\
\hline 1 & I & Production & 43 \\
\hline 2 & II & Finance & 44 \\
\hline 3 & III & Marketing & 49 \\
\hline 4 & IV & Human Resource & 62 \\
\hline 5 & V & $\begin{array}{c}\text { Research \& } \\
\text { Development }\end{array}$ & 67 \\
\hline
\end{tabular}

After conducting the SWOT analysis for the applicable parameters among the organizations, Pearson Correlation analysis was carried to know whether there was any significant correlation between strengths, weaknesses, opportunities and threats.

Table 6 -Pearson Correlation between Strengths, Weaknesses, Opportunities and Threats

\begin{tabular}{|l|c|c|c|c|}
\hline & Strength & Weakness & Opportunities & Threats \\
\hline STRENGTH & 1.000 & $0.544^{*}$ & $0.167^{*}$ & $0.734^{*}$ \\
Correlation & & 0.017 & 0.006 & 0.001 \\
Sig. & & & & \\
\hline WEAKNESS & & 1.00 & $0.867^{*}$ & $0.715^{*}$ \\
Correlation & & & 0.000 & 0.001 \\
Sig. & & & & \\
\hline OPPORTUNITIES & & & 1.000 & $0.708^{*}$ \\
Correlation & & & & 0.001 \\
Sig. & & & & \\
\hline THREATS & & & & \\
Correlation & & & & \\
Sig. & & & & \\
\hline
\end{tabular}

*Correlation was significant at the 0.05 level. Thus it was inferred that the correlation between strengths, weaknesses, opportunities and threats of the organizations was significant.

For a depth analysis, ANOVA has been done for testing whether there was any significant difference in strengths, weaknesses, opportunities and threats.

It was clear as depicted in Table 7; there was no significant difference in strengths, weaknesses, opportunities and threats among the organizations according to the chief executives.
Table 7 -ANOVA - $\quad$ Strengths, Weaknesses, Opportunities and Threats

\begin{tabular}{|c|c|c|c|c|c|c|c|c|c|c|c|c|c|}
\hline \multirow[b]{2}{*}{ Industry } & \multicolumn{3}{|c|}{ Strength } & \multicolumn{3}{|c|}{ Weakness } & \multicolumn{4}{|c|}{ Opportunities } & \multicolumn{3}{|c|}{ Threats } \\
\hline & \begin{tabular}{c|} 
Mea \\
$\mathbf{n}$
\end{tabular} & SD & 第 & $\begin{array}{c}\text { Mea } \\
\text { n }\end{array}$ & SD & 북을 & $\begin{array}{c}\text { Mea } \\
\mathbf{n}\end{array}$ & SD & 국 & & $\begin{array}{c}\text { Mea } \\
\text { n }\end{array}$ & SD & ํํำ \\
\hline $\begin{array}{l}\text { Ceramic and } \\
\text { Refractories }\end{array}$ & 7.00 & $\begin{array}{c}1.4 \\
1\end{array}$ & & 2.50 & $\begin{array}{c}0.7 \\
1\end{array}$ & & 1.50 & $\begin{array}{c}0.7 \\
1\end{array}$ & & & 2.00 & $\begin{array}{c}2.8 \\
3\end{array}$ & \\
\hline $\begin{array}{l}\text { Chemical } \\
\text { Industries }\end{array}$ & 9.67 & $\begin{array}{c}5.0 \\
3 \\
\end{array}$ & & 6.67 & $\begin{array}{c}5.5 \\
1 \\
\end{array}$ & & 5.00 & $\begin{array}{c}2.0 \\
0\end{array}$ & & & 5.33 & $\begin{array}{c}4.1 \\
6 \\
\end{array}$ & \\
\hline $\begin{array}{l}\text { Electrical } \\
\text { Equipment }\end{array}$ & 2.50 & $\begin{array}{c}2.1 \\
2 \\
\end{array}$ & & 4.00 & $\begin{array}{c}4.2 \\
4 \\
\end{array}$ & & 1.50 & $\begin{array}{c}0.7 \\
1 \\
\end{array}$ & & & 3.50 & $\begin{array}{c}0.7 \\
1 \\
\end{array}$ & \\
\hline $\begin{array}{l}\text { Electronic } \\
\text { Industries }\end{array}$ & 8.33 & $\begin{array}{c}5.8 \\
6\end{array}$ & & 7.00 & $\begin{array}{c}5.2 \\
9\end{array}$ & & 5.00 & $\begin{array}{c}1.7 \\
3 \\
\end{array}$ & & & 5.67 & $\begin{array}{c}3.7 \\
9\end{array}$ & \\
\hline $\begin{array}{l}\text { Engineering } \\
\text { Industries }\end{array}$ & 7.33 & $\begin{array}{c}3.2 \\
1\end{array}$ & 의 & 2.33 & $\begin{array}{c}1.5 \\
3\end{array}$ & वु & 1.67 & $\begin{array}{c}1.5 \\
3 \\
\end{array}$ & & & 2.67 & $\begin{array}{c}2.5 \\
2\end{array}$ & 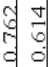 \\
\hline $\begin{array}{l}\text { Plantation } \\
\text { and Agro- } \\
\text { based } \\
\text { Industries }\end{array}$ & 6.33 & $\begin{array}{c}1.1 \\
5\end{array}$ & & 7.33 & $\begin{array}{c}6.3 \\
5\end{array}$ & & 4.67 & $\begin{array}{c}2.3 \\
1\end{array}$ & & & 2.00 & $\begin{array}{c}1.7 \\
3\end{array}$ & \\
\hline $\begin{array}{l}\text { Textile } \\
\text { Industries }\end{array}$ & 2.00 & $\begin{array}{c}1.4 \\
1 \\
\end{array}$ & & 2.50 & $\begin{array}{c}2.1 \\
2 \\
\end{array}$ & & 1.50 & $\begin{array}{c}0.7 \\
1 \\
\end{array}$ & & & 2.50 & $\begin{array}{c}2.1 \\
2\end{array}$ & \\
\hline Total & 6.56 & $\begin{array}{c}3.9 \\
6 \\
\end{array}$ & & 4.89 & $\begin{array}{c}4.2 \\
7 \\
\end{array}$ & & 3.22 & $\begin{array}{c}2.1 \\
8 \\
\end{array}$ & & & 3.50 & $\begin{array}{c}2.8 \\
1\end{array}$ & \\
\hline
\end{tabular}

The opinions of Managing directors or Chief Executives on the overall performance of the various functional areas of the public sector organizations were obtained and Kruskal-Wallis test has been done to know whether there is any difference in between the industrial groups regarding their functional area-wise performance.

Table 8 -Overall Performance of Various Functional Areas in the Organizations

\begin{tabular}{|c|c|c|c|c|c|c|}
\hline \multirow[b]{2}{*}{$\begin{array}{l}\text { Sl. } \\
\text { No: }\end{array}$} & \multirow[b]{2}{*}{ Responses } & \multicolumn{5}{|c|}{ Functional Area } \\
\hline & & $\begin{array}{l}\text { Human } \\
\text { Resource } \\
(\%)\end{array}$ & $\begin{array}{c}\text { Finance } \\
(\%)\end{array}$ & $\begin{array}{l}\text { Production } \\
(\%)\end{array}$ & $\begin{array}{l}\text { R\&D } \\
(\%)\end{array}$ & $\begin{array}{c}\text { Marketing } \\
(\%)\end{array}$ \\
\hline 1 & Very Good & $\begin{array}{c}0 \\
(0.00 \%)\end{array}$ & $\begin{array}{c}3 \\
(16.67 \%)\end{array}$ & $\begin{array}{c}1 \\
(5.55 \%)\end{array}$ & $\begin{array}{c}0 \\
(0.00 \%)\end{array}$ & $\begin{array}{c}1 \\
(5.55 \%)\end{array}$ \\
\hline 2 & Good & $\begin{array}{c}11 \\
(61.11 \%)\end{array}$ & $\begin{array}{c}9 \\
(50.00 \%)\end{array}$ & $\begin{array}{c}11 \\
(61.11 \%)\end{array}$ & $\begin{array}{c}4 \\
(22.22 \%)\end{array}$ & $\begin{array}{c}10 \\
(55.56 \%)\end{array}$ \\
\hline 3 & Satisfactory & 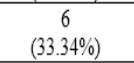 & $\begin{array}{c}4 \\
(22.22 \%)\end{array}$ & $\begin{array}{c}4 \\
(22.22 \%) \\
\end{array}$ & $\begin{array}{c}10 \\
(55.56 \%)\end{array}$ & $\begin{array}{c}7 \\
(38.89 \%) \\
\end{array}$ \\
\hline 4 & Poor & $\begin{array}{c}0 \\
(0.00 \%)\end{array}$ & $\begin{array}{c}2 \\
(11.11 \%)\end{array}$ & $\begin{array}{c}1 \\
(5.55 \%)\end{array}$ & $\begin{array}{c}4 \\
(22.22 \%)\end{array}$ & $\begin{array}{c}0 \\
(0.00 \%)\end{array}$ \\
\hline 5 & Very Poor & $\begin{array}{c}1 \\
(5.55 \%)\end{array}$ & $\begin{array}{c}0 \\
(0.00 \%)\end{array}$ & $\begin{array}{c}1 \\
(5.55 \%)\end{array}$ & $\begin{array}{c}0 \\
(0.00 \%)\end{array}$ & $\begin{array}{c}0 \\
(0.00 \%)\end{array}$ \\
\hline & Total & $\begin{array}{c}18 \\
(100.00 \%)\end{array}$ & $\begin{array}{c}18 \\
(100.00 \%)\end{array}$ & $\begin{array}{c}18 \\
(100.00 \%)\end{array}$ & $\begin{array}{c}18 \\
(100.00 \%)\end{array}$ & $\begin{array}{c}18 \\
(100.00 \%)\end{array}$ \\
\hline & Mean Scores & 3.5 & 3.72 & 3.56 & 2.67 & 3.67 \\
\hline \multirow{2}{*}{\multicolumn{2}{|c|}{$\begin{array}{l}\text { Kruskal-Wallis test } \\
\text { (between Industrial } \\
\text { groups) }\end{array}$}} & $\chi^{2}=5.56$ & $\chi^{2}=7.24$ & $\chi^{2}=5.80$ & $\chi^{2}=5.07$ & $\chi^{2}=3.16$ \\
\hline & & P-value $=0.352$ & $\begin{array}{l}P \text {-value }= \\
0.203\end{array}$ & $\begin{array}{l}\text { P-value }= \\
0.326\end{array}$ & $\begin{array}{l}P \text {-value }= \\
0.407\end{array}$ & $\begin{array}{l}\text { P-value }= \\
0.676\end{array}$ \\
\hline
\end{tabular}

Table 8 revealed that the mean scores of human resource, marketing, production and finance were above 3 , but in case of research and development is was less than 3. It indicated the fact that the performance of research and development department was not up to the mark. Also the results of Kruskal-Wallis test showed that in all functional areas, there is no difference in their performance in between different industrial groups at $5 \%$ level of significance.

\subsection{Performance of Human Resource Management}

Majority of the human resource departments of the selected 18 units were following external source of recruitment and agreed that the procedure has affected the performance of organizations. The selection 
procedures were including preliminary screening, interview and aptitude tests. They were having a very good induction and placement system along with the assessment of training needs. Even thought, there were shortages of manpower in many areas and also the number of employees sent for training per year remained very low when compared to their strength in the organizations with the duration of less than a week. They are satisfied with the remuneration packages, promotion policy and procedures, performance appraisal system, industrial relation climate, functioning of welfare measures and voluntary retirement scheme. On the other hand they were of negative opinion towards employees' role in corporate decision making, absenteeism level and organizational development programmes.

Further, Chi-square tests for proportion were done to know whether there was any significant proportion in training programmes and in case of performance appraisal system. The results thus generated were given in Table 5 and Table 6 respectively.

Table 9 -Chi-square Test for Proportion - Training

\begin{tabular}{|c|c|c|c|c|}
\hline Response & $\begin{array}{c}\text { Whether } \\
\text { training } \\
\text { needs } \\
\text { assessed }\end{array}$ & $\begin{array}{c}\text { If yes, } \\
\text { whethe } \\
\text { r it } \\
\text { fulfil } \\
\text { needs }\end{array}$ & $\begin{array}{c}\text { Average } \\
\text { no: } \\
\text { trained/y } \\
\mathbf{r}\end{array}$ & $\begin{array}{c}\text { Average } \\
\text { duration } \\
\text { (days) }\end{array}$ \\
\hline Yes & $\begin{array}{c}12 \\
(66.67 \%) \\
*\end{array}$ & 8 & \multirow{2}{*}{128} & \multirow{2}{*}{37} \\
\cline { 1 - 2 } No & $\begin{array}{c}6 \\
(33.33 \%)\end{array}$ & 4 & \\
\cline { 1 - 2 } NA & $0(0.00 \%)$ & 6 & & \\
\hline
\end{tabular}

$*$ As Chi-square value $=2.0$ and $\mathrm{P}$-Value $=0.157$, it was concluded that the proportion for training programmes was not significant at 5\% level of significance.

Table 10 -Chi-square Test for Proportion-Performance Appraisal System

\begin{tabular}{|c|c|c|}
\hline Response & $\begin{array}{c}\text { Whether } \\
\text { there is } \\
\text { a } \\
\text { performance } \\
\text { appraisal } \\
\text { system }\end{array}$ & $\begin{array}{c}\text { If yes, } \\
\text { whether } \\
\text { it is done } \\
\text { regularly }\end{array}$ \\
\hline Yes & $13(72.22 \%) *$ & $13(72.22 \%)$ \\
\hline No & $5(27.78 \%)$ & $0(0.00 \%)$ \\
\hline NA & $0(0.00 \%)$ & $5(27.78 \%)$ \\
\hline
\end{tabular}

*As Chi-square value $=3.556$ and P-Value $=0.059$, it was inferred that the proportion of performance appraisal system was not significant at $5 \%$ level of significance

\subsection{Performance of Financial Management}

Most of the finance departments among the selected 18 units were having capital restructuring, with a sound capital budgeting system with the method of internal rate of return. They do not have large amount on receivables due to the presence of a proper system for its collection. But the working capital position was not appreciative. Only a few responded that their auditing was not up-to-date and social auditing system was absent in many cases.

\subsection{Performance of Production Management}

Heads of production departments revealed that they were having proper production planning and control measures which contributed towards the improved performance in the organizations. The capacity utilization was fluctuating year by year mainly due to breakdown of machineries, power failure and lack of regular orders. The state of materials management were not that much commendable. They are having systems for vendor evaluation and rating along with inventory control which met the production requirements. Most organizations were adopting $\mathrm{ABC}$ analysis for analyzing inventories. They were getting the raw materials as per standard specification in terms of quality. There were negotiations in purchasing and the percentage of purchase rejection/rework was at the lower end which amounts to less than 5\%. Most heads were keeping equipment availability at the optimum level and followed breakdown maintenance. Also the time loss due to break downs were very less as generators was present in all organizations. They were supported with the presence of frequently modified material requirement planning system and given importance to Ergonomics. It is further noticed that most of those heads were not incorporating PERT/CPM systems in their departments.

In addition, Chi-square tests for proportion were also made to check whether there was any significant proportion in production planning as well as that of material requirement planning. Table 11 and Table 12 disclose the output of the analysis.

Table 11 -Chi-square Test for Proportion - Production Planning

\begin{tabular}{|c|c|c|c|}
\hline Response & $\begin{array}{l}\text { Whether } \\
\text { there is } \\
\text { planning } \\
\text { \& control } \\
\text { measures }\end{array}$ & $\begin{array}{c}\text { If yes, } \\
\text { whether it } \\
\text { contributed } \\
\text { to } \\
\text { improved } \\
\text { performanc } \\
\text { e }\end{array}$ & $\begin{array}{c}\text { Is } \\
\text { planning } \\
\text { sales } \\
\text { forecasting } \\
\text { based }\end{array}$ \\
\hline Yes & $\begin{array}{c}15 \\
(83.30 \%) \\
*\end{array}$ & $15(83.30 \%)$ & $\begin{array}{c}14 \\
(77.80 \%)^{*} \\
*\end{array}$ \\
\hline No & $\begin{array}{c}3 \\
(16.70) \%\end{array}$ & $0(0.00 \%)$ & $4(22.20 \%)$ \\
\hline NA & $0(0.00 \%)$ & $3(16.70) \%$ & $0(0.00 \%)$ \\
\hline
\end{tabular}

$*$ Chi-square value $=8.0$ and $\mathrm{P}$-value $=0.005 . * *$ Chi-square value $=16.33$ and $\mathrm{P}$-value $=0.00$.

$83.30 \%$ organizations have proper production and control measures and the Chi-square test shows that it was significant at 5\% level of significance. Also $77.80 \%$ organizations have production planning based on sales forecasting which was significant at $5 \%$ level of significance. 
Table 12

Chi-square Test for Proportion - Material Requirement Planning System

\begin{tabular}{|c|c|c|}
\hline Response & $\begin{array}{c}\text { Whether there } \\
\text { is } \\
\text { material } \\
\text { requirement } \\
\text { planning } \\
\text { system }\end{array}$ & Percentage \\
\hline Yes & 15 & $83.30^{*}$ \\
\hline No & 3 & 16.7 \\
\hline Total & $\mathbf{1 8}$ & $\mathbf{1 0 0}$ \\
\hline
\end{tabular}

${ }^{*}$ Chi-square value $=8.0$ and P-value $=0.005$. Results of Chi-square test for proportion inferred that the proportion of organizations having material requirement planning system was significantly higher at 5\% level of significance.

As the absence of PERT/CPM system were made during the response of production heads, a Chi-square test for proportion was carried out to explore whether there was any major proportion in PERT/CPM system followed then. The results thus generated were given in Table 13.

Table 13

Chi-square Test for Proportion - PERT/CPM System

\begin{tabular}{|c|c|c|}
\hline Response & $\begin{array}{c}\text { Whether } \\
\text { there is } \\
\text { well-designe } \\
\text { d } \\
\text { PERT/CPM } \\
\text { system }\end{array}$ & Percentage \\
\hline Yes & 3 & $16.70^{*}$ \\
\hline No & 15 & 83.30 \\
\hline Total & $\mathbf{1 8}$ & $\mathbf{1 0 0}$ \\
\hline
\end{tabular}

$*$ Chi-square value $=8.0$ and $\mathrm{P}$-value $=0.005$. Chi-square for proportion showed that the proportion of organizations having well-designed PERT/CPM system was significantly lesser at $5 \%$ level of significance.

5.5 Performance of Research and Development Management

With respect to the response of research and development heads, only a few organizations were there not having the presence of separate functional area among the organizations and those having were using modern technology and functioning satisfactorily. But they lacks in case of modernization of existing plans due to shortage of proper funds. It was also noted that, there was absence of performance evaluation system among research and development departments, even though those organizations were benefiting from them. In addition, there were no instance of commercialization and they don't come under the purview of WTO. The percentage of turnover allocated for research and development was less than $5 \%$ only.

\subsection{Performance of Marketing Management}

The lack of marketing affected the overall performance of the organizations in spite of well planned marketing strategies. They also failed in developing god setup for service clients of the organizations and the present level of servicing was found to be unsatisfactory due to lack of manpower and advertisements. Even though, they were able to meet the delivery schedules largely by managing a good distribution network through customer database system.

Table 14 and Table 15 reproduced shows the results of Chi-square test for proportion to assess whether there was any significance in well planned marketing strategy and customer database system.

Table 14

Chi-square Test for Proportion - Well Planned Marketing Strategy

\begin{tabular}{|c|c|c|}
\hline Response & $\begin{array}{c}\text { Whether } \\
\text { there is } \\
\text { well-planne } \\
\text { d } \\
\text { marketing } \\
\text { strategy }\end{array}$ & $\begin{array}{c}\text { If no, whether } \\
\text { thinking } \\
\text { to evolve the } \\
\text { same } \\
\text { in future }\end{array}$ \\
\hline Yes & $13(72.20 \%)$ & $5(27.80 \%)$ \\
\hline No & $5(27.80 \%)$ & $0(0.00 \%)$ \\
\hline NA & $0(0.00 \%)$ & $13(72.20 \%)$ \\
\hline Total & $\mathbf{1 8 ( 1 0 0 \% )}$ & $\mathbf{1 8 ( 1 0 0 \% )}$ \\
\hline
\end{tabular}

${ }^{*}$ Chi-square value $=3.56$ and $\mathrm{P}$-value $=0.059$. Chi-square made clear that the proportion of organizations having well-planned marketing strategy was not significantly lesser at $5 \%$ level of significance.

Table 15

Chi-square Test for Proportion-Customer Database
System

\begin{tabular}{|c|c|c|}
\hline Response & $\begin{array}{c}\text { Whether } \\
\text { there is } \\
\text { customer } \\
\text { database } \\
\text { system }\end{array}$ & $\begin{array}{c}\text { Average } \\
\text { percentage of } \\
\text { difference after } \\
\text { implementation }\end{array}$ \\
\hline Yes & $\begin{array}{c}11 \\
(61.10 \%) \\
*\end{array}$ & \multirow{2}{|}{9} \\
\hline No & $\begin{array}{c}7 \\
(38.90 \%)\end{array}$ \\
\hline Total & $\begin{array}{c}\mathbf{1 8} \\
(\mathbf{1 0 0 \%})\end{array}$ \\
\hline
\end{tabular}

$*$ Chi-square value $=0.889$ and $\mathrm{P}$-value $=0.346$. Chi-square made clear that the proportion of organizations having customer database system was not significantly lesser at $5 \%$ level of significance.

5.6 Performance Evaluation Model Development

With a view to develop a performance evaluation model, all the 42 public sector industrial organizations under manufacturing sector in Kerala were selected for the study. Statistical tests were conducted to analyze the effect of various parameters on net profit/loss made over the period of time. To analyze the casual impact of various factors on a macro framework, multiple regression was attempted with the net profit/loss as the dependent variable and 19 indicators viz., working capital, capital invested, capital employed, net worth, net assets, employment, production, income, expenditure, turnover, capacity utilization, return on investment, debt-equity ratio, current ratio,

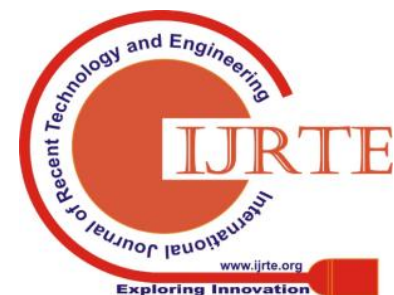


receivables on sales, stock of finished goods to sales, stock of raw materials to consumption and consumption to sales as independent variables. The results obtained from step-wise regression analysis, conducted among the organizations under different industry groups were summed up and given in Table 16.

Table 16 depict the fact that capital invested (CI) and net worth (NW) emerged as the most pivotal parameters where as capital employed (CE) was next vital factor along with turnover (TO)

It can be deciphered that higher the technology, the capital invested (CI) and net worth (NW) play a role and lower end the capital employed (CE) has a role. The ranking of applicable parameters based on t-value was done and given in Table 17.

\section{Table 16}

Results of Step-wise Regression Analysis among Industry Groups

\begin{tabular}{|c|c|c|c|c|c|c|c|}
\hline $\begin{array}{l}\text { Sl. } \\
\text { No: }\end{array}$ & Industry Group & & $\begin{array}{r}\text { plicable } \\
\text { Para } \\
\text { t-valu }\end{array}$ & $\begin{array}{l}\text { erforma } \\
\text { aters } \\
\text { (sig.) }\end{array}$ & & $\begin{array}{c}\text { F- } \\
\text { Value }\end{array}$ & $\begin{array}{c}\text { Adjusted } \\
\mathrm{R}^{2}\end{array}$ \\
\hline 1 & $\begin{array}{l}\text { Ceramic and } \\
\text { Refractories }\end{array}$ & $\begin{array}{c}\mathrm{CI} \\
2.928 \\
(0.026)\end{array}$ & \begin{tabular}{|c|}
$\mathrm{NW}$ \\
2.69 \\
$(0.031)$
\end{tabular} & - & -- & $\begin{array}{c}5.698 \\
(0.034)\end{array}$ & 0.74 \\
\hline 2 & $\begin{array}{l}\text { Chemical } \\
\text { Industries }\end{array}$ & $\begin{array}{c}\text { T0 } \\
3.84 \\
(0.012)\end{array}$ & $\begin{array}{c}\mathrm{NW} \\
-2.27 \\
(0.034)\end{array}$ & - & -- & $\begin{array}{c}4.930 \\
(0.049)\end{array}$ & 0.629 \\
\hline 3 & $\begin{array}{l}\text { Electrical } \\
\text { Equipment }\end{array}$ & $\begin{array}{c}\mathrm{NW} \\
6.03 \\
(0.001)\end{array}$ & \begin{tabular}{|c|} 
T0 \\
4.05 \\
$(0.005)$ \\
\end{tabular} & - & -- & $\begin{array}{l}40.064 \\
(0.00)\end{array}$ & 0.897 \\
\hline 4 & $\begin{array}{l}\text { Electronic } \\
\text { Industries }\end{array}$ & $\begin{array}{c}\mathrm{CI} \\
8.5 \\
(0.00)\end{array}$ & -- & -- & -- & $\begin{array}{l}72.18 \\
(0.00)\end{array}$ & 0.888 \\
\hline 5 & $\begin{array}{l}\text { Engineering } \\
\text { Industries }\end{array}$ & $\begin{array}{c}\mathrm{CI} \\
2.56 \\
(0.022) \\
\end{array}$ & \begin{tabular}{|c|} 
T0 \\
2.7 \\
$(0.019)$ \\
\end{tabular} & \begin{tabular}{c|}
$C E$ \\
-3.97 \\
$(0.008)$ \\
\end{tabular} & - & $\begin{array}{l}20.08 \\
(0.002)\end{array}$ & 0.851 \\
\hline 6 & $\begin{array}{l}\text { Plantation and } \\
\text { Agro-based } \\
\text { Industries }\end{array}$ & $\begin{array}{c}\mathrm{CI} \\
-4.76 \\
(0.002) \\
\end{array}$ & \begin{tabular}{|c|}
$\mathrm{CE}$ \\
3.77 \\
$(0.002)$ \\
\end{tabular} & - & - & $\begin{array}{c}15.42 \\
(0.003)\end{array}$ & 0.762 \\
\hline 7 & Textile Industries & $\begin{array}{c}\mathrm{NW} \\
7.97 \\
(0.001) \\
\end{array}$ & \begin{tabular}{|c|}
$\mathrm{CI}$ \\
7.12 \\
$(0.001)$ \\
\end{tabular} & \begin{tabular}{c|} 
PRDN \\
4.55 \\
$(0.006)$ \\
\end{tabular} & $\begin{array}{c}\text { CPUT } \\
2.95 \\
(0.032)\end{array}$ & $\begin{array}{l}46.27 \\
(0.00)\end{array}$ & 0.892 \\
\hline 8 & $\begin{array}{l}\text { Wood-based } \\
\text { Industries }\end{array}$ & $\begin{array}{c}\text { ROI } \\
8.57 \\
(0.00) \\
\end{array}$ & $\begin{array}{c}\mathrm{CE} \\
4.33 \\
(0.003)\end{array}$ & -- & - & $\begin{array}{l}43.48 \\
(0.00)\end{array}$ & 0.904 \\
\hline
\end{tabular}

Table 17

\section{Ranking of Applicable Parameters based on t-value}

\begin{tabular}{|c|l|c|}
\hline Sl. No: & \multicolumn{1}{|c|}{ Parameters } & Rank \\
\hline 1 & Capital Invested & I \\
\hline 2 & Net Worth & II \\
\hline 3 & Turnover & III \\
\hline 4 & Capital Employed & IV \\
\hline 5 & Return on Investment & V \\
\hline
\end{tabular}

Further, ranking of applicable parameters was done for technology driven organizations as well as non-technology focused conventional industry groups. The results were tabulated as shown in Table 18 and Table 19 respectively.
Table 18

Ranking of Applicable Parameters for Technology Driven Organizations

\begin{tabular}{|c|l|c|}
\hline Sl. No: & \multicolumn{1}{|c|}{ Parameters } & Rank \\
\hline 1 & Capital Invested & I \\
\hline 2 & Turnover & II \\
\hline 3 & Net Worth & III \\
\hline 4 & Capital Employed & IV \\
\hline
\end{tabular}

Table 19

Ranking of Applicable Parameters for Non-technology Driven Organizations

\begin{tabular}{|c|l|c|}
\hline Sl. No: & \multicolumn{1}{|c|}{ Parameters } & Rank \\
\hline 1 & Capital Invested & I \\
\hline 2 & Net Worth & II \\
\hline 3 & Capital Employed & III \\
\hline 4 & Return on Investment & IV \\
\hline
\end{tabular}

Thus, it can be learnt that, even though there were many variables taken for the study in Kerala, in order for a long term survival and sustenance, it was important that capital invested, net worth and capital employed play a crucial role and hence the public sector industrial organizations under manufacturing sector in Kerala have to consider this very seriously.

\section{FINDINGS AND SUGGESTIONS}

The various findings evolved from this study was summed up and given below.

General Observations

1. There were 42 public sector industrial organizations under manufacturing sector in Kerala which belongs to eight industry groups. The major chunks were under plantation and agro-based, chemical and engineering groups.

2. Many of them were functioning almost as appendages of the state government and the management very often consists of chosen representatives of the ruling party.

3. Need for more capital investment in the organizations was very much felt.

4. There was lack of professionalism in the organizations.

5. Absence of separate cell for monitoring the performance of various departments in the organizations.

Corporate Management

6. Most of the organizations were having sufficient tenure of experience in the field and rolled-out their first product without much delay.

7. The average tenure of chief executives was 3 to 5 years which found to be insufficient and resulted in the adverse performance of the organizations.

8. The organizations were unable to perform as per the corporate plan due to the absence of proper decision making system.

9. There was no difference in the effectiveness of various systems in between the various industrial groups among organizations studied. 
10. Production department ranked first among other departments and research and development department lags behind all other functional areas.

11. The correlation between strengths, weaknesses, opportunities and threats of the organizations was found to be significant. Also, there was no significant difference in strengths, weaknesses, opportunities and threats among the organizations according to the chief executives.

12. There was no difference in their performance of functional areas in between different industrial groups.

Human Resource Management

13. Human resource departments were following external source of recruitment and selection procedures were including preliminary screening, interview and aptitude tests.

14. There were shortages of manpower in many areas and the training facilities were not utilized properly. The proportion for training programmes and performance appraisal were not significant.

15. The remuneration packages, promotion policy and procedures, performance appraisal system, industrial relation climate, functioning of welfare measures and voluntary retirement scheme were commendable.

16. Employees' role in corporate decision making, absenteeism level and organizational development programmes were not appreciable.

Financial Management

17. The organizations were having a sound capital budgeting system with the method of internal rate of return.

18. They do not have large amount on receivables due to the presence of a proper system for its collection.

19. The working capital position was not appreciative.

20. Only a few responded that their auditing was not up-to-date and social auditing system was absent in many cases.

Production Management

21. The capacity utilization was fluctuating year by year mainly due to breakdown of machineries, power failure and lack of regular orders.

22. Majority of the organizations have proper production and control measures and it was significant. They have production planning based on sales forecasting which was also significant.

23. The state of materials management was not that much commendable, even though they were equipped with systems for vendor evaluation and rating along with inventory control which met the production requirements.

24. Most organizations were adopting $\mathrm{ABC}$ analysis for managing inventories.

25. They were getting the raw materials as per standard specification in terms of quality.

26. There were negotiations in purchasing and the percentage of purchase rejection/rework was at the lower end.

27. Most organizations were keeping equipment availability at the optimum level and followed breakdown maintenance.

28. The time loss due to break downs were very less as generators was present in all organizations.
29. The presence of frequently modified material requirement planning system was noted. The proportion of organizations having material requirement planning system was significantly higher

30. The production heads were given importance to Ergonomics.

31. Most of organizations were not incorporating PERT/CPM systems in their production departments. The proportion of organizations having well-designed PERT/CPM system was significantly lesser.

Research \& Development Management

32. Among the selected organizations, a very few organizations were not having the presence of separate functional area of research and development.

33. They were using modern technology and functioning satisfactorily. On the other hand, they lacks in case of modernization of existing plans due to shortage of proper funds.

34. There was absence of performance evaluation system among research and development departments, even though those organizations were benefiting from them.

35. There were no instance of commercialization and they don't come under the purview of WTO.

36. The percentage of turnover allocated for research and development was merely less than $5 \%$.

Marketing Management

37. In spite of well planned marketing strategies, the lack of marketing affected the overall performance of the organizations. The proportion of organizations having well-planned marketing strategy was not significantly lesser.

38. They also failed in developing god setup for service clients of the organizations and the present level of servicing was found to be unsatisfactory due to lack of manpower and advertisements.

39. They were able to meet the delivery schedules largely by managing a good distribution network through customer database system by managing all the above mentioned hurdles. Also, the proportion of organizations having customer database was not significantly lesser.

Performance Evaluation Model Development

40. Capital invested and net worth were the applicable performance parameters for the industry group ceramics and refractories.

41. The parameters applicable for the performance evaluation of chemical industry group were turnover and net worth.

42. Under electrical equipment industry group, net worth and turnover were predominant among applicable parameters.

43. While considering the electronic industry group, the only parameter applicable was capital invested.

44. In case of engineering industry group, capital invested, turnover and capital employed were the major ones.

45. Plantation and agro-based industry group was having capital invested and capital employed as the applicable parameters.

46. For textile industry group, the parameters applicable were capital invested and net worth.

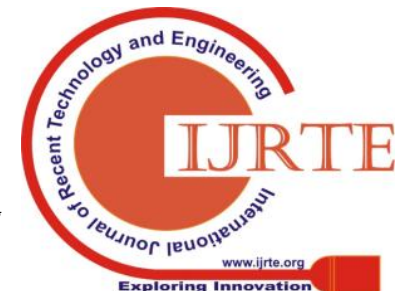


47. Return on investment and capital employed were pivotal

48. While considering all the eight industry groups together, capital invested and net worth were emerged as the most important parameters followed by capital employed and turnover.

49. Even though, there were many parameters were taken for the study, in Kerala, in order for a long term survival and sustenance, it was found that capital invested, net worth and capital employed play a crucial role.

Based on the findings obtained as the output of this research study, the following suggestions were made for the betterment of public sector organizations under manufacturing sector in Kerala.

\section{General Suggestions}

1. As the public sector industrial organizations in Kerala were functioning almost as appendages of the state government and the management often consists of chosen representatives of the ruling party, the autonomy of organizations must be clearly outlined and maintained continuously.

2. Funds required for capital investment may be made available in time so that, they organizations may have a fair chance to recover.

3. Professionalism to be introduced should not be merely in terms of certain degrees, but well-experienced professional managers with appropriate skills would have to be brought in.

4. The director board should comprise of professional directors, functional directors and elected representatives from the employees.

5. The terms of chief executives should be larger to provide stability and enable them to formulate and implement long-term policies in the interest of the organizations. They should also be allowed to function unhindered and freely.

6. There should be a general framework of qualifications for the top management posts in line with respective industry group.

7. Periodic seminars and conferences should be organized by the state government to get an overview on the working of the organizations and sort out the problems without further delay.

8. A separate cell may be made responsible for monitoring the performance of organizations.

9. Efficiency and productivity will have to be the hallmarks of the organizations' future operations, as in ultimate analysis they determine the success in pursuit of set goals.

Suggestions for Corporate Management

10. Strategic corporate planning may be improved so that there id better efficiency in planning.

11. Decision making and implementation process in the organizations should be handled more effectively by the concerned authorities.

12. A working group may be setup with a view to monitor periodic evaluation of various departments in the organizations.

Suggestions for Human Resource Management

13. Wherever the organizations have surplus manpower, a well-conceived programme of rationalization should be with respect to woo-based industry group.

evolved. This may involve either diversification or expansion of the organizations or operating a VRS or retaining the surplus to take-up activities like ancillary production, transport and marketing of the organizations.

14. Training for all employees in the organizations should more frequently be done so that, they might acquire better expertise, skill and motivation for contributing to the organization. Effective workers' education programmes may be conducted routinely.

15. The major portion of any increase in remuneration would be linked with productivity.

16. An incentive system may be introduced to reduce absenteeism.

17. Measures to stop multiplicity of trade unions may be taken. Otherwise, the scope for collective bargaining and participative management become limited.

18. Organizational development programmes may be developed in all the organizations.

Suggestions for Financial Management

19. The organizations have to gear up its machinery to achieve better recovery of receivables with a view to improve its working results.

20. Special attention should also be drawn to improve the working capital position in the organizations.

21. A social auditing system should be developed in the various organizations.

Suggestions for Production Management

22. The capacity utilization should be stepped up with a view to make the production levels more competent.

23. Steps should be taken to reduce the percentage of purchase rejection/rework in the organizations.

24. A quality control cell may be provided in those organizations where such a system was not in existence.

25. PERT/CPM systems may be introduced in the organizations with a view to improve the production programmes and schedules.

Suggestions for Research \& Development Management

26. Immediate steps should be taken to start separate research and development department in the organizations where they were not present and also to modernize the existing technology flowing in those organizations.

27. Adequate investments should be made in the organizations to facilitate technology absorption and up-grading.

28. Periodical assessment on the functions of the department should also be made.

29. Innovations brought about by the research and development department should be commercialized.

30. The organizations may be put under the purview of WTO.

Suggestions for Marketing Management

31. Well-planned marketing strategies should be developed in the organizations, especially in the context severe competition in the wake of globalization programme.

32. Good setup should be mode to impart proper service to the clients of the organization.

33. The distribution network should be improves so that the turnover of the 
organization could have a quantum leap in the future

34. The advertising system prevailing in the organizations for the promotion of their goods/products and services needs advancements. The organizations can think of utilizing government media for this purpose.

Suggestion regarding Model Development

35. In order for a long term survival and sustenance, it is important that capital invested, net worth and capital employed play a major role and hence, the public sector industrial organizations under manufacturing sector in Kerala have to consider this very seriously.

\section{CONTRIBUTION TO THE SOCIETY}

The public sector industrial organizations under manufacturing sector in Kerala, of the important segments of public sector in India and their performance is highly critical to the success of Indian economy. Thus, these organizations need to perform to the best satisfaction of their stakeholders. The two major questions need to answer in resolving this issue of their satisfactory performance:

$>$ What could be the techniques of measuring the performance?

$>$ What could be done to minimize the excessive government controls on these organizations for enabling them to function as business enterprises?

The study has revealed that the total performance of the organizations cannot be measured in terms of physical and financial indicators alone. A unified problem solving approach to performance evaluation could be a good solution for this ticklish issue.

As far the performance of public sector industrial organizations under manufacturing sector in Kerala is concerned, during the recent years however, things have changed for the better. The future of these organizations does not necessarily look too bleak. The initiative of the state government to reform and restructuring the existing organizations is on solid grounds. As the state progress on various fronts, the public sector industrial scenario is also likely to brighten up due to the new approach of the government. The trade unions too on its part have shown some change in their stand and they are not as militant as before. The public sector, in future, is expected to perform better and generate more revenues for reinvestment and there by stop being

a public burden. It will also continue to be a tool in the hands of the government to achieve a variety of socio-economic objectives. The globalization programmes and opening up of economy has an effect on the functioning of these public sector industrial organizations and thereby caused policy planners to make noticeable changes. The awareness to conserve the scarce resources, especially energy and environment has put more responsibility on the management of public sector industrial organizations. As worker participation improves along with the introduction of modern management practices, the performance of public sector industrial organizations is bound to show good results in future.

\section{REFERENCES}

[1]. "A Review of Public Enterprises in Kerala", Bureau of Public Enterprises, Government of Kerala, 1995-2004.

[2]. Altman Edward, "Corporate Bankruptcy Prediction and its Implications for Commercial Loan Evaluation", The Journal of Commercial Bank Lending, December 1970

[3]. Altman Edward, "Financial Ratios, Discriminant Analysis and Prediction of Corporate Bankruptcy", The Journal of Finance, Vol. 23, September 1970 .

[4]. Beaver, H, "Financial Ratios as Predictors of Failure", Empirical Research in Accounting - Selected Studies 1996, Institute of Professional Accounting, January 1967.

[5]. Blum Marc, "The Failing Company Doctrine", Unpublished $\mathrm{PhD}$ Dissertation, Columbia University, 1969.

[6]. "Britannica Ready Reference Encyclopaedia", (Set of 10 Volumes), Encyclopaedia Britannica (India) Private Limited, 1999.

[7]. Edminister Robert, "Financial Ratios and Credit Scoring for Small Business Loans", The Journal of Commercial Bank Lending, September 1971.

[8]. Edminister Robert, "Financial Ratios as Discriminant Predictors of Small Business Failure", Unpublished PhD Dissertation, The Ohio State University, 1970

9]. Ewert David, "Trade Credit Management: Selection of Accounts Receivables using Statistical Model”, Unpublished PhD Dissertation, Stanford University, 1968.

[10]. Finnerty John D, "Corporate Financial Analysis", McGraw-Hill International Editions, Singapore, 1986.

[11]. Hickman W.B, "Corporate Bond Quality and Investor Experience", Princeton University Press, Princeton, 1958.

[12]. Johnson Craig G, "Ratio Analysis and the Prediction of Firm Failure", The Journal of Finance, December 1970.

[13]. Marwin C, "Financing Small Corporations, New York", Bureau of Economic Research, 1942.

[14]. May O. George, "Truth in Accounting”, University of Pennsylvania Press, Philadelphia.

[15]. Robert Morris Associates (RMA), Annual Statement Studies, Philadelphia: 1958-66.

[16]. Sapru R.K, "Management of Public Sector Enterprises in India", (Set of 2 Volumes), Ashish Publishing House, 1987.

[17]. Smith R.F \& Wincar A.H, "Changes in the Financial Structure of Unsuccessful Corporations", University of Illinois, Bureau of Business Research, 1935.

18]. Srinivasan R, "Strategic Management: The Indian Context", Prentice-Hall of India Private Limited, 2002.

[19]. Trivedi P \& Gopal V, "MOU and Other Performance Improvement Systems - A Comparison”, Public Enterprise ICP, Ljubljana, 1990.

[20]. Trivedi P \& Vithal H.P, "Menu of Financial Indicator used in MOUs: An Exercise in Clarification", Working Paper Series, Indian Institute of Management, Kolkata, 1992

[21]. Trivedi Prajapati (Ed), "Memorandum of Understanding - An Approach to Improving Public Enterprise Performance", International Management Publishers, New Delhi, 1990.

[22]. Zeppou M \& Sotiraku T, "The STAIR Model: A Comprehensive Approach for Managing and Measuring Government Performance in the Post-Modern Era", International Journal of Public Sector Management, Vol: 6, No: 4, 2003. 